\title{
Foreword to the Special Issue
}

DOI: $10.1134 / \mathrm{S} 1068162014060132$

From June 30 to July 4, 2014, the 7th All-Russian Conference "Proteolytic Enzymes: Structure, Functions, and Evolution" was held in Petrozavodsk, Russia. The Conference was organized by the Institute of Biology of the Karelian Research Center, Russian Academy of Sciences; the Shemyakin-Ovchinnikov Institute of Bioorganic Chemistry, Russian Academy of Sciences; the Department of Biological Sciences of the Russian Academy of Sciences; and the Scientific Council for Bioorganic Chemistry of the Russian Academy of Sciences. Financial support was provided by the Russian Foundation for Basic Research and the Conference sponsors, the Bruker company and GE Healthcare Life Sciences.

The Conference gathered over 100 participants from Moscow, Saint Petersburg, Pushchino (Moscow oblast), Petrozavodsk, Kazan, Murmansk, Novosibirsk, Perm, Tomsk, Ufa, Borok (Yaroslavl' oblast), Nizhni Novgorod, and Vladivostok, as well as Minsk (Belarus) and Baku (Azerbaijan) (virtual participation).

The Program of the Conference contained six plenary lectures, 41 oral presentation, and 43 posters. Besides, 20 works were presented virtually. The reports were grouped in 6 scientific sections:

1. Modern trends in proteolysis studies. Bionanotechnology.

2. New proteolytic enzymes; proteomics.

3. Structure-function relationship and molecular mechanisms of action of proteases. Protein-protein interactions.

4. Regulatory functions and regulation of protease activity.

5. Proteases and their inhibitors in biotechnology and medicine.
6. Proteolytic enzymes in biochemical adaptations. Evolution of proteases.

Traditional fields of studies of proteolytic enzymes covered the issues of protease isolation and characteristics, structure analysis, investigation of the active center structure and mechanisms of action of various classes of the enzymes, and their evolutionary classification issues. At the same time, new approaches and methods in protease studies, including the proteomics technologies, were discussed and the possibilities of application of the new information technologies in studies of proteolytic enzymes and their inhibitors were considered.

Much attention was paid to the discussion of proteolysis as a regulatory mechanism and investigation of the contribution of both individual proteases and major proteolytic systems of the cell.

Many works were presented in the section "Proteases and their inhibitors in biotechnology and medicine." Here, questions discussed included the role of proteases and their inhibitors in oncogenesis, immunity, progression of viral infections, as well as meningococcal and HIV infections, effects of bacterial toxins, etc. New data on blood clotting and fibrinolysis system were presented.

The Journal issue is compiled from the materials presented at the Conference in Petrozavodsk. The rest of the works received by the Editorial Board from the author teams who participated in the Conference will be published in the up-coming issues of the Journal.

Compiling Editors of the Issue Prof. L.D. Rumsh, Prof. T.V. Rotanova, and Dr. E.N. Kaliberda 